\title{
紀州藩の木材供給機構とその建築生産 に及ぼした影響に就いて
}

\section{まえがき}

建築技術は江戸初期に於いて最早一応の限界に達して いたが、他方建築生産方式に「請負」という新たな型式 を生えだ事は、その時代特色を示するのとして注目され る。註建築資材が完全に商品化され、商業資本の下に建 築生産機構が置かれてくると、今迄工事で主導的立場に あつた大工桩梁の如き技術者の存在以上に、工事を企業 として成立せしめるに必要な経済機構が重要性を帯びて くる。中でる造営費の大半を占める木材を供給する形態 の役割は大きいるのと推定される。

そこで本稿では、熊野という豊富な木材資源を支配し ていた紀州藩をとりあげ、まずその木材供給機構が如何 様に発生発展したかを明らかにし、次にそれが江戸末期 に至つてはたした紀州藩建築生産機構に於ける役割を考 察したいと思う。

註 江戸初期請負飞就いては, 川上貢氏「近世初期飞 於ける建築生産の諸相」(建築学会研究報告第 19 号, 1952）及び伊藤要太郎氏「江戸時代前期飞於ける建築生 産の業態就いて」（建筑学会研究報告第 21 号, 1953） の論考で明らかである。更に渡辺保忠氏は建築学大系第 4 巻口本建築史近世篇（彰国社、1957年刊）で統一的な 考察をなされて抢られる。

\section{1. 木材供給機構}

建築生産の為に木材を供給する業態は紀州藩に2つあ つた。1つは民間商業機構の「材木問屋」で、他は藩営 商業機構「御仕入方」の組織である。古来有名な熊野木 材を一般市場へ搬出寸る方法は江戸初期に於いて專ら 「材木問屋」を主体とする商人の手飞委対られていた。 併し藩による地方産業育成の傾向が著しくなるに従つて そうした民間商業に対抗する業態として「御仕入方」が 発生する。本節ではそれ等 2 機構を分析して、汇戸末期 紀州藩の建築生産へ大きな影響を与へると至つた母体を 明磪にしよう。

\section{1-1. 民間木材供給機構一新宮材木問屋}

紀州に於ける木材資源は熊野川を中心として開発され ていた。その熊野川は上流とて北山川と十津川に分岐し ているから、紀州というょりはすしろ勢州飞近い北山地 方と大和国志野郡の木材子熊野川问口の新宮へ運ばれと いた。従つて当地方の材木問屋は、新宮に於いて発生し

\footnotetext{
* 東京工業大学大学院生
}

$$
\text { 準会員内藤 }
$$

昌*

\author{
且又発展したのである。
}

\section{1-1-1. 新宮材木問屋の発生年代}

正保 4 年(1647)11 月 17 日「新宮佪船問屋中委先例改 定」（日本林制史資料和歌山藩所収註1-1以下これを林制 資料所収之略記する）には佪船問屋の材木積入心得・買 論等の詳細な規定があり、そこに材木問屋の存在が知ら れる棓1-2。更とその定の末尾承応 4 年:(1655) 6 月11日 改として船問屋、新宮町中年寄と共飞材木問屋安兵衛以 下33人の名前が記されている。従つて後1-1-2, 1-1-3で 示めす様な近世的商業機構としての新宮材木問层は1650 年前後に成立していた事を認められるが、前期的形態は 去れより20年程さかの淁るるのと見られる。即ち、延宝 9 年 (1681) 7 月 2 日材木問屋衆が奉行所へ各自の営業 開始時期を報告した記録「新宮材木問屋書上」（林制資 料所収)によれば、第 1 表の如く 2 代以来（1 代を 20 年 平均として 1681 年より逆算す礼ば寬永末年) の問屋が 他仁比べて压倒的飞多い。3 代（元和末年）以来の 3 ケ は最古の部に属するが、はたしてここで問題とする様な 近世的問屋であつたかどうか不明である。管見する処、 当地木材供給事情を示めす最古の記録宽永 13 年 (1636) 12月「奥熊野山林御定書兼先年之触書」一には庄屋頭百 姓等在方の者が関係している事は知られるが、材木問屋 は認められない。

結局新宮材木問屋は 1630 年頃より漸次発生を見たと 思われるが、問屋としての形態を整えたのは 1650 年頃 と考劣られるのである。

第 1 表 新宮材木問屋営業開始期

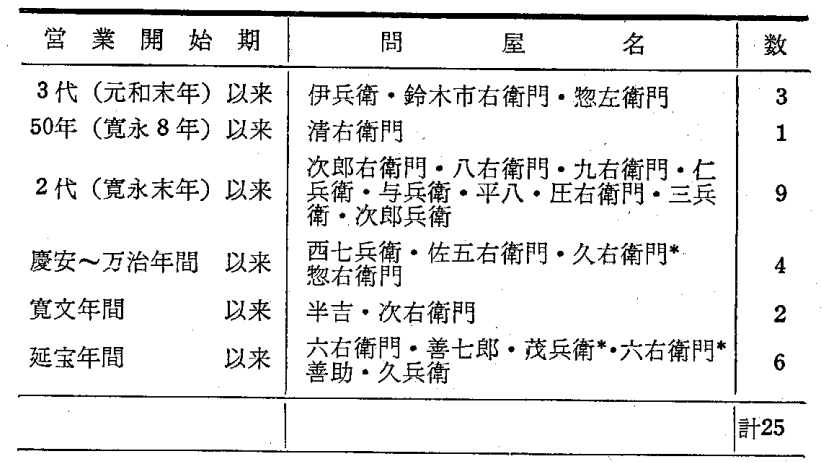

$\triangle 1$ 代を20年平均として延宝 9 年より逆算したもの

$\triangle{ }^{*}$ 印の3軒は「かり家」で営業し，他は全部家持である。

$\triangle$ 延宝年間以来の六右衛門家持は, 20年以前(寬文年間) に問屋を していたが，中絶し，後改ぬて仲間へ入つている。 


\section{1-1-2。材木問屋仲間の形成}

第 2 表は「新宮佪船中委先例万改定」「寛文 4 年定」 「寛文11年定」「新宮材木問屋書上」(以上林制資料所収） 「材木問屋仲間定之写」(新宮材木誌所収)諳1-3によつて 新宮材木問屋の数を調べたものである。

\section{第 2 表 新宮材木問屋数}

\begin{tabular}{|c|c|c|c|c|c|}
\hline 年 代 & $\begin{array}{c}\text { 㴍底 } 4 \text { 年 } \\
(1655)\end{array}$ & $\begin{array}{l}\text { 寛畜 464 年 } \\
(1664)\end{array}$ & $\begin{array}{c}\text { 寛交11年 } \\
(1671)\end{array}$ & 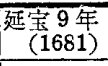 & $\begin{array}{l}\text { 文华15年 } \\
\text { (1818) }\end{array}$ \\
\hline 数 & 33 & 29 & 26 & 25 & 20 \\
\hline
\end{tabular}

これにこると 1650 年前後にはとの数にかなりの変動 が見られ、問屋衆が所謂仲間組織へ変化する胎動期的様 相を示めしている。この頃彼等が取り決めた事柄は、仲 間組織自体を意識した内容は少なく、材木市場を調整す る為の取引規定が多い。例光ば「新宮迴船中委先例改定」 は材木積出時に於ける廻船問屋との商取引を規定したも のであり、慶安 3 年 (1650) 3 月 13 日「江戸にて上ゲ材 木之党」(林制資料所収) 性積出材木品種品質の制限を定 めたものである。註1-4更に「宽文 4 年定」る木材規格に 対して寸法不足時の差引銀高を示して招り註1 155 決して同 業者組織としての仲間制の機構自体を問題としたるので はない。即ち、この期沉於ける彼等は仲間を組織化する 事よりる、木材を完全なる商品とするために、まず規格 化を行い、品質を整党、品種を定めて、材木問屋の信用 を高める事に専念していたわけで、貨幣経済の新しい潮 そ対処していたのである。

さてそうした胎動期的様相も 1680 年頃になると一つ の固定した状態を示めして来る。材木問屋数は第 2 表の 如く延宝 9 年 (1681)の 25 へ収斂する傾向を明確にして いる。そして貞享 2 年 (1685)「問屋之法書追加」（新宮 材木誌所収）では借銀にて仕入れた木材や同一人が名儀 を変党他へ仕出した木材は元の問屋へ返却すべき事等の 取引規則の外に、月 1 回問屋衆が会合して仲間内の諸件 を議し、新しい取引を組頭へ報告する義務を申し合せて いて、仲間内の横の連熬を密にする事が意識的に行われ ている。即ちここに至つて新宮材木問屋仲間は名実共に 組織化されたのである。留意すべきは、この組織ふ決し て幕府や紀州藩の行政方針飞よつて上からの力で形成さ れたものではない事で、むしろ彼等自身が貨幣経済機構 の中にあって市場調整の為自然発生的に組織化されたと 考光られるのである。

\section{1-1-3. 株仲間への変遷}

第 1 表延宝 9 年の材木問屋 25 軒中 3 軒虾借家で営業 していた。併し仲間制が進展して彼等の枢益を保護する 為には市場を独占しょうとする排他的㑯向を強めて来て 、やがて借家では営業が不可能になる。即ち 元 䘵 2 年 (1689) 4月「問屋仲間心得定」(新宮材木誌所収)飞よる と、新たに営業する場合借家では認可しない事が規定さ れている。時にこの民間木材供給機構に対して藩営の木
材供給組織「御仕入方三役所」が形成されて、最早材木 市場は新宮材木問屋衆の独占する処ではなくなつて来 た。（次節参照） その上藩主治貞は安永 4 年 (1775) 以 降藩財政建て直しを積極的に行い（南紀徳川史第 1 巻参 照）商業組織への規制も抢のずから強くなり、藩の行政 力は新宮材木問屋仲間内部に大きく侵入する結果となつ た。ここに新宮材木問屋は今迄の内仲間的性格から、藩 の公認を得た所謂株仲間へと変遷するのである。

文政 10 年 (1827) 10 月「材木問屋中へ申隻書」（林制 資料所収）では、それ迄営業して来た材木問屋へ藩が株 札を発行して営業を許可し、諳1-6市場統一を計つてい る。併しこの時既に材木問屋仲間内では株数の制限を行 つていた。即ち、新宮材木誌によれば文化期には株数を そ定め子々孫々相伝えて営業し、若し新たに材木問屋を するには株を買収せねばならず、その值は 10〜50 両程 であつたという。又、文化 15 年（1818）「材木問屋定之 写」によれげ取引規定の内容は先にあげた貞享 2 年「問 屋之法書追加」とほとんど同一であつて大差ない。唯仲 間制を強化する傾向が一層強烈である点は以前に見られ なかつた事で、例壳ば每月 8 日定期会合を開き、も乙欠 席の場合は前もつてその欠席の理由を申出るか名代を出 席させる必要があり、更に養子る仲間衆と相談しなけれ ばならず、それ等違反者は仲間から除外された。結局新 宮材木問屋仲間は江戸末期に於いて藩の統制下にあつた 点は注目すべきであろうが、商取引形態は先の形成期と 本質江於いて類似したもので、何等発展的要素恃認めら れない。

\section{1-2 藩営木材供給形龍—一御仕入方三役所}

\section{1-2-1. 御仕入方三役所の発生要因}

17世紀後半熊野术材は新宮材木問屋によつて市場へ供 給されていた。彼等問屋衆は材木市場を独占する為に木 材規格を定め品質を保証し品種を規定して信用を高め、 更に仲間組織を作つて発展して行つた事は既儿前節で述 べて来た処である。その新宮材木問屋の発展は木材を完 全なる商品とする貨幣経済の発展を前提としている。貨 幣経済の波に乗つて彼等木材商人は大いに利殖を貪つた のであるが、他方材木を保護育成していた熊野在方百姓 層は貪困の度を増々強めて行つた。「御仕入方三役所発 端」(南紀徳川史第12巻所収)によれば熊野百姓の疲幣に より藩財政を支える年貢は滞る一方となり動摇を来たし ている為彼等を何等かの手段で救済する必要とせまら れていたそこで案出されたのが半官半民の木材販売組織 御仕入方三役所である。従つてこの組織を発生せしめた 直接の原因は材木商人の嬉頭にあるのであつて、換言す ればこの組織は紀州藩が営えだ材木問屋なのである。機 業内容は新宮材木問屋の取引方法をそのま導入したと 考觉てよい。彼等が供給した木材性新宮材木問屋が販売 した木材と同じ様に商品として規格化されて招り品質品 
種の保証をともなつた。それ故ここでは御任入方の営業 状態を問題とする必要は無いるのと考党、主としてこの 組織が紀州藩政体に発展して行つた過程を分析して次節 の前論としたい。以下前記「御仕入方三役所発端」及び 「文化五問辰十一日進達書」を中心とした南紀徳川史第 12 巻所収の諸記録によつて考察を武夕る。

\section{1-2-2. 御仕入方三役所の形成}

前記目的の為に藩営事業として活動するのは元禄13年 (1700)和歌山洿入御仕入方役所を設置した事に殆柰る。 併しそれ以前既にこうした組織体の発生をうながす存在 があつた。即ち佐八役所と入谷役所（亭保 4 年天野川役 所と改名、以下これを天野川役所とする）である。

佐八役所怔明暦 2 年 (1656) 势州宮川上流大杉山の材 木を搬出する為澄生した。又天野川役 芹は元禄 12 年 （1699）十津川上流和州天野川郡入谷山を紀州藩で買受 け用材を積出した時に始つた。

それ等三役所一御仕入、佐入、天野川一は宝暦 3 年 (1753)合併迄は夫々独立して括り、事業内容も単一では なかつた。例兄ば合併直後宝暦 6 年 (1756) 9 月 2 日今 迄の組織では役所設立の趣旨である在方百姓救助飞役立 姑佐入役所一御仕入役所から役人を派出せしめている のは先の間の事情を物語るものであろろ。菲1-8

三役所の中心的存在御仕入役所註1-9創立にあたつて町 人が仕込多飞活躍して括り、又享保 15 年 (1730) 飞は町 手代老雇入れ、更に延享 2 年 (1745) 頭取鈴木次兵衛は 在方頭取より兼任している等、藩営組織でありながら藩 の官僚が直接関係していない点注目すべきである。それ 等の人々は商買にひいでていたと見え、百婎救済の本来 の目的とは逆化思わしくない藩財政を助ける為 14〜15 万両も差上げている。

からうに成功した事業もやがて藩官僚の支配する所と なつて、延享年間より町手代が減少する傾向を示めし、 遂炡宝糜 3 年 (1753) 御仕入 ・佐八・天野川三役所性合 併する。そして明和 2 年 (1765) 立石喜太夫が頭取に任 ぜられてからは藩政体と同様相続制が生まれ、商売の才 智に豊えだ人材は失われていつた。

\section{1-2-3. 御仕入方三役所の改革}

文化 2 年 (1805) 御仕入方三役所の組織は再編成され る事となつた。この改革で重要な点は潘官僚の支配が上 部組織に残留してはいたものの、取引を実際に行ろ下部 組織は発生期の如く町方在方手代飞よつて構成された事 で、藩財政の最高枢力者勘定奉行がこの組織頭取を兼務 したり、勘定奉行退役後頭取勤務を行つたりしている。

この改革は成功したと見てよく、事業対象も前期の如 く紀州領内に限らず全国的規模になり、文化14年(1817) 3 月大坂幸橋御屋敷认御仕入方役所が出来、続いて同 15 年 3 月に江户八丁堀に、文政 6 年 (1823) 11 月泉州堺 飞同 7 年月飞江州大津飞、同 8 年 2 月京都に、天保 4 年
(1833） 12 月兵庫にと間断なく発展している。

かくして蓄積した商業資本は、不安定な藩財政にとつ て大きな意味を持つて来るのは当然である。本来潘政体 とは別個の存在であつたこの組織は、その势力が拡大す るままに藩に於ける立場は勘定奉行の様に重要なものに なつている。今迄の単に材を販売するという建築生産 にとつて間接的役割に代つて、藩の作事に直接関係を持 つに至るのである。

註 1-1. 昭和 6 年 朝陽会発行

註 1-2. 新宮超船問屋中委先例改定

問屋付送り状にて下り材木売渡申らへに，山中より出 入上有之由断候とも，代銀取渡し不々仕内侯八、材木取 返し置。可申候，代銀取渡仕，以後申来候八、買主方一

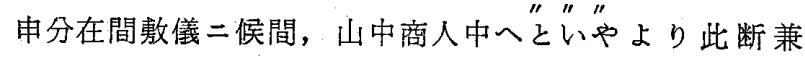
而二可申_渡事

註 1-3. 昭和初年, 新宮木村商同業組合事務所発行

註 1-4. 江戸飞て上り材木之覚

一, 何二而もふしなしの類, 一杉ものの類, 一, 桧もの の類, 一, 槻ものの類, 一, 柏ものの類, 一, 功木も のの類, 一, 何二ても間切板之類いたご

右之外材木八何二てる上ヶ申間敷候、いらたをて売 可申筈船頭登り候迄売レ不申候は，其時上ケ置候とる主 そ見合で可仕候，若背申二をるて八過料金子壱両出しレ 可申三為後一日連判仍上如件

註 1-5. 定

一，諸材木不足は七寸角より壱尺五寸角迄八正五分之不 足迄八不上苦候, 六分占壱寸迄、銀五分引、壱寸壱分 壱寸五分迄、銀壱多引、壱寸六分占式寸迄、銀式多引、 其上之不足木八右同前之皘引，可申候，是八已，正月 6 定申分。

一, 諸材木症引二如先年-之上㾟も引可上申侯。

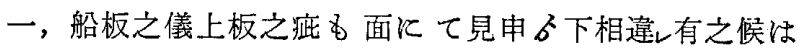
疪引可仕候。

一，諸材木手取二買申間敷候。

一, 極月中は相対次策沅可仕候。

右之通趈船問屋中並舟宿立合相談仕, 材木問屋架へ断, 相談を以相究違背二為申間_敷加判仕候, 若相背申わの 有之候は，過料銀壱枚急度申付，其上中間をはっしレ可 申侯、 二為後一日加判仍上如件。

註 1-6. 材木問屋中人申渡書

此度御改正二付株ニレ被二成御—定候二付, 其方共是迄 仕来候問屋株之義, 先年之通符物一式支配二被仰_付候。 此度相改銘々江株札壱枚ツッ下ヶ遣候間，持伝手态商売 ᄂ可致候……後略……

註 1-7. 拙稿：「江戸時代木材供給形態の研究 1」, 紀州藩（関東支部研第23回発表会梗概集）飞て詳述して ある。

註 1-8，南紀徳川史第 12 巻 $347 \mathrm{p}$ 参照。 
註 1-9. 御仕入方三役所々云兄ば和歌山湊の御仕 入, 勢州の佐八, 和州の天野川の三役所指し, 単飞御 仕入役所と云えば和歌山湊の役所を指す。

註 1-10 例えば, 西山与七郎は勘定奉行として御仕 入方頭取を兼務し, 野口太郎介は勘定奉行より御仕入頭 取を被命している。

\section{2. 建築生産機構に於ける御仕入方の発展}

紀州藩の木材供給機構一新宫材木問屋、御仕入方三役 所一は民間及び潘の営業差こそあれ、夫々文化年間に入 つて大きな変化をきたしている。即ち、新宮材木問屋は 株伸間として次第に排他的閉鎖的業態と化し、材木商人 の自由な活動には穿屈な枷となつた。他方、御仕入方三 役衣以藩の政治的枢力を背崇貨幣経済の波に乗つて順 調に資本蓄積を行い、疲弊した紀州藩財政には無二の支 柱となつていた。そこで本節では、紀州潘建冧生産機構 に於ける御仕入方三役所の役割を分析して、材木供給形 態の建築生産へ与兄た影響に就いて考察したいと思う。

\section{2-1. 紀州藩建築生産機構}

まず紀州藩潘職制に於汁る造営機棈を明らかにしよ う。江戸幕府の作事組織は田辺泰博士の論文「江戸幕府 作事方職制に就いて」䛨2-1でその内容を知る事が出来る。 各潘の職制は幕府のそれに従つている故、建築生産機構 も幕府に類似したものである事は当然予想される。註2-2 唯紀州藩の場合、幕府に比べると規模小さく、熊野とい ろ巨大な太材資源を持つていた為、藩財政が破綻に落ち 入つた江戸末期に於いては種々の変形を生じている。 1800 年代の紀州藩職制は「御役順」(南紀徳川史第 8 巻所収)によれば次のA〜Hの8 階級と「御役順之無之 筋」という特別職の計 9 層に分けられる。

【階級 A】一老中より御供番頭迄22役にして、重役とい い、礼式時には大広間席に列する。

【階級B】一御用人より布衣御目付迄 24 役にして、布衣 己上といい、孔雀之間席に列する。

【階級 C】一松坂奉行より御匙医迄23役にして、頭取と いい、孔雀之席並であつた。

【階級D】一御留守居番頭より御数寄屋頭迄33役にして 平士といい、虎之間席に列する。

【階級 E】一友ケ島御番組頭より御同朋迄49役にして、 平士といい、虎之間席並であつた。

【階級 F】一御城代支配小普請より平士総領迄37役飞し て、平士といい、中之間席に列する。

【階級 G】一布衣御免之辈より御勘定奉行支配小普請迄 80役にして、御目見己下という。

【階級 H】一伊賀組頭以下53役にして、紀州藩の最下層 官僚郡である。

【特別職】一御役順之無之筋といい、22役あつた。

さて、上記紀州藩官僚郡の層別分化を基準にして、建 築生産と関係ある諸職を表示したのが第 3 表である。各
役職名右上の記号は前記階級順位を示めして括り、左下 カッコ内の数字は並祿高を表わす。例えば、階級Fr ある ${ }^{12 / 37}$ 御大工頭(15) とは、礼式時中之間原に列する平士 37役中第12位にして、並高は15石という意味である。か ように各機構が完備したのは文化 9 年 (1812) 総御材木 奉行職設置以後の事であるが、大様は 1800 年代紀州藩建 築生産諸機構の状態を示めすものである。この組織の特 色をあげれば

a）大普請䋅行以外のすべての役職は勘定奉行が支配 している。この事は幕府の作事・小普請・普請等の諸奉 行が勘定奉行上別個飞独立して存在し、老中及び若年寄 に支配されているのに比べ大きな相違点である。組織が 幕拊より悢るか、小さい為と推定される。

b ）藩の作事はすべて勘定奉行を通じて行われる。従 つて作事に必要な資金の調達及び運用は、勘定奉行直属 役人一御勘定組頭、御勘定、支配勘定組頭一等が担当し た。

c）普請奉行と共に大普請奉行が存在した。普請・大 普請にとの業務上明確な区別があつたとは工事した対象 を見ても考光られないが、大普請奉行は普請奉行に比べ 軍事上重要な工事を行つていたと思われ、それが故に勘 定奉行の支配から離れて独立し、勘定奉行以上の地位を 得ていたのであろう。な怙穴太役の職掌は土工石坦築造 を司る事にめつたので大普請奉行支配にあつたものの普 請奉行にも属した。

d）作事関係では、作事奉行を筆頭にして、技術系に は大工頭(町方在方建築工事関係諸職人支配)があり、管 理事務系に作事吟味役、同元 $ン$ 諸手代があつて基本的に は幕府と同様である。唯作事下奉行は存在しないが、大 きな工事になると（例党ば後述和歌山城嘉永 3 年再建工 事）それに相当するものとして御作事奉行助なる役職が タろけられていた。

e ）総御材木奉行は文化 9 年 (1812) 6 月 28 日新設さ れ、同 13 年 (1816) 御材木石奉行と改名された。これは 專任職でなく御仕入方三役衣頭取が兼務した。即ち材木 を管理する業務担当者御材木石奉行は、本来大れ飞管理 さるべき木材販売前態御仕入方三役所に支配されたわけ である。

f）その御仕入方三役所は前節で考察した如く、半官 半民の構成よりなる木材供給機構である。従つて、藩職 制に於いては正統的な地位はなく特別職であつた。実際 には勘定奉行と同様な枢力を持つていたものの、淥高は 勘定奉行の 400 石に比べはるか、少い50～60石程度であ つた。御材木石奉行を兼水て造営資材を調達し、その商 業資本を背景に建築生産機構で演じた役割は極めて大き W。

\section{2-2. 嘉永 3 年和歌山城再建工事}

弘化 3 年 (1846) 7 月 26 日和歌山城は落雷により焼 
第 3 表 紀州藩建築生産関係組組図

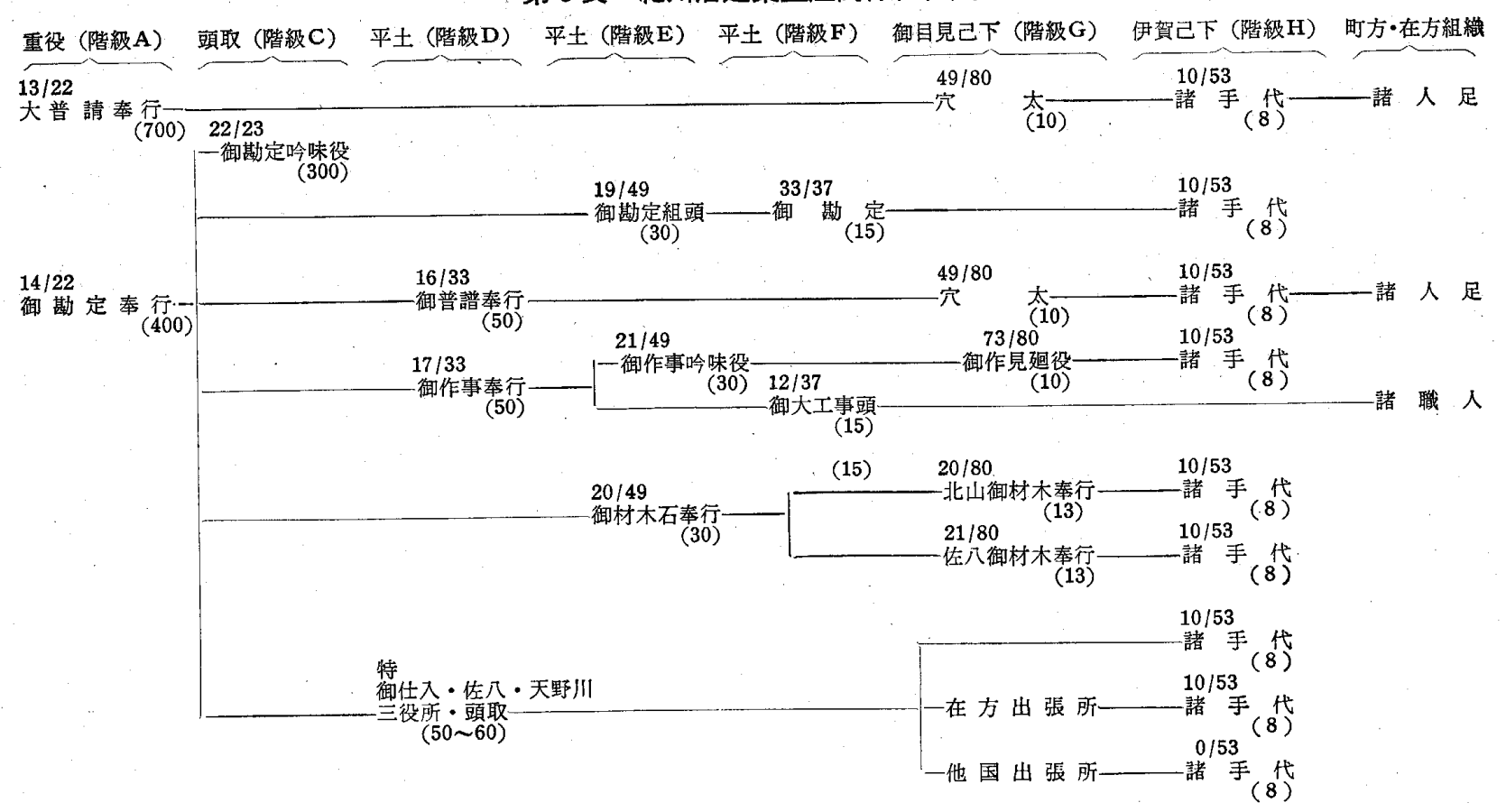

失、当時幕府の制として天守再建は許可されぬのが一般 であつたのを特請願し、この期最大の工事が行われる 事となつた。そこでその造営が如何様に行われたかを考 察してみよう。

和歌山城の沿革、再建のいきさつ、様式、工費に就い ては既に藤岡通夫博士の論文「和歌山城天守とその造営 そ就いて」で明らかにされている。それを参照させてい ただき、更に「御天守再建御用掛り被仰付」(南紀徳川 史第 2 巻所収)「御役順」(同前第 8 巻所収)「嘉永 3 年再 建和歌山城棟札写」「御天守御普請帳」を資料として、 この造営が如何に行われたかを図表化したのが第 4 表で ある。

さてこの工事の特色をあげれば、

a）再建事業はこの時代既に一般化されていた請負形 式でなく藩直営である。その意味から典型的潘作事とい える。大普請奉行を除き紀州藩建築生産関係のすべての 組織が関係している。

b）本来ならば普請奉行は作事奉行と同一層にあるべ きだが、この工事は焼跡築造するものであつた為か土 木工事は少く、従つて役割は軽く、その結果格下げられ たと思われる。

c）御大工頭中村吉五郎は本来階級 F の 12/37 である が、造営の為昇進して階級Dの 20/33 御供番格になつて いる。

d ）問題は御仕入方三役所の立場である。建築資材供 給の計画を担当し、頭取南出平左衛門は御勘定吟味役格 に昇格している。御勘定吟味役格とは並禄 300 石の役職 で単に御仕大方三役所頭取の50〜60石にして「御役順之 無之筋」といろ本来の役職よりはるかル高いるである。
総工費銀 $1.666 \times 545$ 目中竹木他 $1.067 \times 600$ 目（約64 \%) を費した業務の担当故当然の傾向と云兄ようが、御 材木石奉行として御作事奉行の下に活躍する本来の形式 と比べ注目すべき現象である。最も伝統的格式を重ずる この和歌山城造営に於いて、わざわざ藩主直属の役人御 供番頭格御広教御用人稲葉司書を折々御仕入方罷出御用 筋取扱として附置せしめ、御仕入方三役所頭取を登用し た事は、その役が潘職制では格が低いだけに重要であ る。では極く一般の作事では如何であろろか。

\section{2-3 御仕入方の建築工事}

元来この組織は材木商人の嬯頭に対抗して形成された 木材販売機構である事は既に前節で論じた。それが和歌 山城造営に上記の如く大きな役割を演じているのだか ら、時の建築生産市場への進出は著しいと見なければな らない。その進出過程を示めせば

(1)文化 4 年 (1807) 江戸中屋敷普請飞は前記和歌纠城 と同型式にて資材供給を行つている。この工事は費用が 少くして立派江出来た為、江戸にも珍しい手際として藩 主上り賞揚され、御船手方にての造船工作にもこの方式 を適用している。註2-8即ら、直営工事として御仕入方が 作事に参加する建築生産の方法はこの時より始まつたの である。

(2)文化 9 年 (1812) 総御材木奉行 (同 13 年御材木石 奉行と改名）新設され、御仕入万頭取の兼務となつた。 註2-4ここに正式に藩職制の上で建築生産機構へ参加出来 たわけである。

(3)文化12年（1815）5月22日以来御仕入方頭取は御材 木石奉行として御作事行見分の場衣へ自由出入が認可さ れた。註2-9 


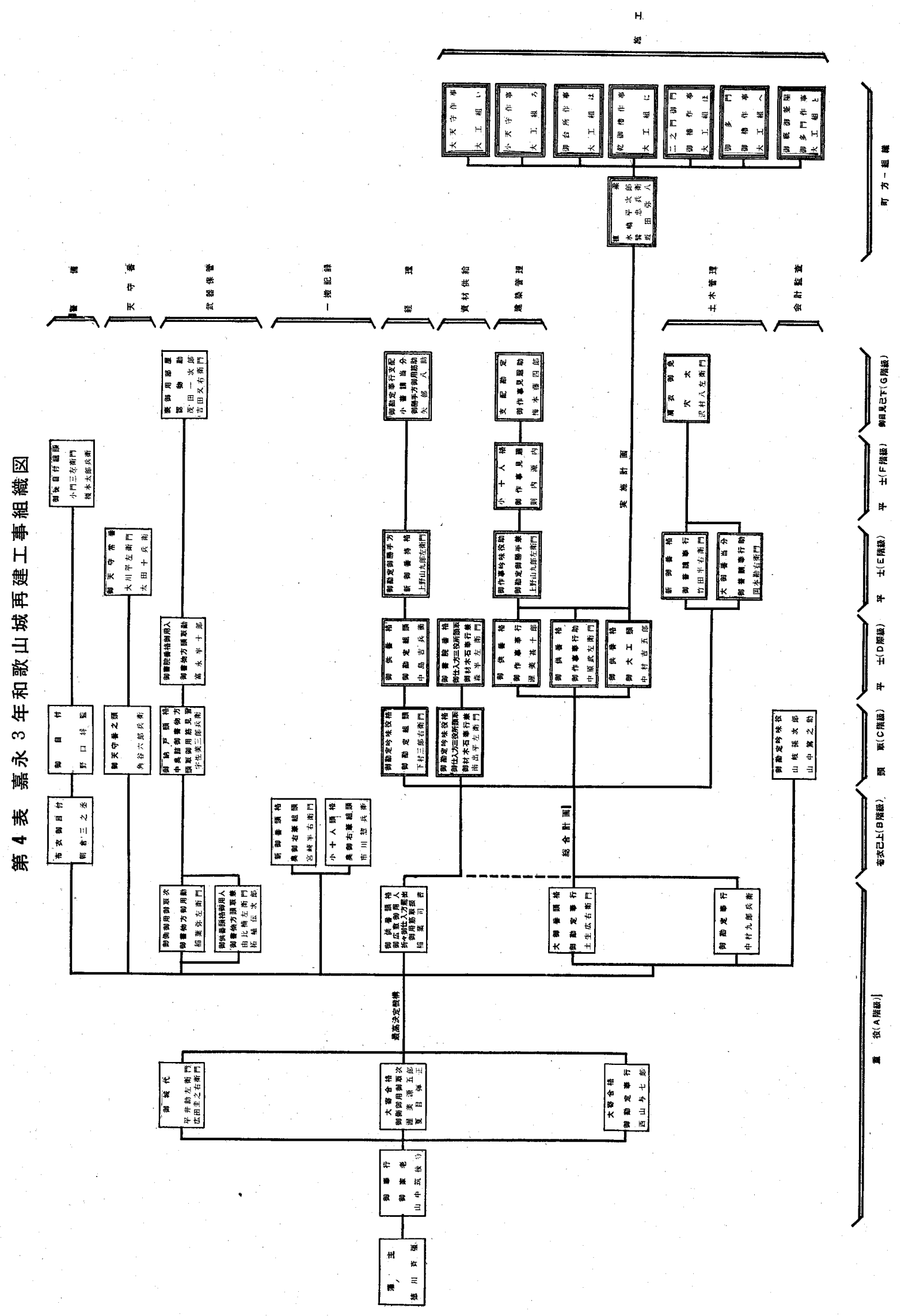


(4)文政13年 (1830) 閠 3 月 24 日南龍院樣御霊屋を御仕 入方が一手飞造営した。䛨2-10 即ち勘定奉行一作事奉行 一大工頭の正統的方式によらずに、御仕方頭取井上兵次 郎が土事を請負つたのである。ここに至り御仕入方の組 織が建築生産で主動的役割を演じたわけである。

(5)天保 4 年 (1833) 2 月 10 日更に西浜大奥御普請名御 仕大方にて行われた。その時の記録と……是迄モ追々御 仕入方二テ大造之御用相勤猶又此度右御用筋相勤候段全 其方儀兼々心掛骨折候故卜一段之儀思召侯毎々一手ニテ 御用勤候段大儀二八候得共猶此上一統申合精々相勤可申 卜之事候……と㐫り、御仕入方で請負う生産方式が藩の 作事として如何隹重用されたかがうかがわれよう。

最後に頭取井上兵次郎の経歷を調べて見ると、御仕入 方手代より追々取立てられた、家の格式低く商人的色彩 の強い役人であつた事は注目に值しょう。先に和歌山城 再建工事にて 紹介した南出平左衛門にしても同様であ る。勿論彼等化建築技術の智識が特別あつたとは考兄ら れない。巨大な商業資本を肯景にして建築工事を請負う いわば企業家としての能力に秀でた人達なのであろう。

\section{むすひ}

以上紀州江於敌る 2 つの木材供給機構の変遷過程を考 察して来た。それより次の 4 点が結論される。

(1)新宮材木問屋は年頃上り漱次発生し、貨幣経済の発 達と共に取报万木材は品質が整えられ規格化されて、 1650年頃完全なる商品となつた。註2-12 そして問屋衆は 1680年前後飞「仲間」を組織した。

(2)熊野の材木市場独占し、枢益を擭護せんが為に新

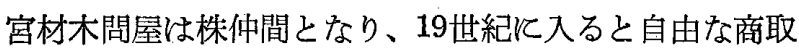
引には抵抗の多い保守的業態と化した。

(3)材木商人によりその利益を剶奪されていた熊野百姓 の疲䌘は著しく、元祿 13 年 $(1700)$ 彼等を救済する為水 半官半民の材木販売業態御仕入方三役所が発足した。い わば藩の営む材木問屋の形成である。

(4)19世紀新宮材木問屋は業態として頭うちの状態にあ つたのに対し、御仕入方三役所恃紀州藩の政治的枢力を 肯景にして增々発展し、そろして蓄積した商業資本より 建築生産機構への進出が始まつた。即ち、材木を商品と する商業資本が作事方とは別個に工事を請負つたのであ る。この過程は封建势力が商業資本炕寄生せざるを得な からた江戸末期の建築生産方式として把握される。

(1957.12.初稿、1958.5.再稿)

註 2-1. 建築雑誌 598 号 (1935年刊) 所收

註 2-2. 浅野家飞代つて徳川頼宜が紀州飞移封され た元和 5 年（1619）当時の藩度体は軍事組織をなしてい
た為，後に見られる様なピラミット的官僚組織を整えて いない。即ち，藩主老中飞各組織体が単一飞附属する簡 素なものであつた。「南竜院様御入国御供姓名録」(南紀 徳川史第 8 巻所収) 飞よると, 普請奉行一井上仁右衛門 500 石，下村三太夫 200 石一及び大工頭一中村讃岐 300 石, 同伊織 130 石はあつたが，後の作事奉行大普請奉行， 材木奉行は存在しなかつた。るつとる大普請奉行は, こ 材封偶然見当らないだけの事であつて，その役職は既に 存在していた。南紀徳川史第 5 巻飞よれば, 近藤平右衛 閒は大坂役で有功し大普請秦行として 1,000 石を受け， 元和 4 年に死亡している。

註 2-3. 南紀德川史第 8 巻498Pの記録江……御作事 普小請方文化九申年九月廿九日右新規被付候右役所俨定 所内へ相遺候事, 同年十月廿四日, 此度御作事小普請方 被仰所々御破損御繥向之儀御作事方同様取計候等之事… とある。幕府の建築工事は作事奉行系統とは別飞小普請 奉行系統の大工でも行われていたので岕るが，紀州藩も 一時的飞は，それ飞類似した組織があつたと思われる。

註 2-4. 南紀徳川史第 8 巻 $159 \mathrm{P}$ 同年（交化 9 年 筆者註）六月廿八日総御材木奉行新設御仕入頭取兼務勤 方以御材木御用且御山々井御木材御入用取締可勤事。

註 2-5. 建筑学会論交集第17号 (1940年刊) 所収

噇 2-6. これは本工事の棟梁水島家飞蔵する記録で 既飞藤岡博士により紹介されている。

註 2-7. 南紀德川史第 17 巻 $854 \mathrm{P}$ 交化四未四月十 四日執政上り御勘定奉行へ達書 江户御中屋敷御普請之 儀御繰合次第可被仰出候間御材木之儀可成丈御領分御山 より仕出さて末々稼にも相成候样此節より手組申付御費 用無之様勘弁致し取計可申々の御事，右仕出方佐八御任 入方へ申付勘弁致させ夫々承御手行宣様差図可致候

註 2-8. 南紀徳川史第 17 卷 $861 \mathrm{P}$ 文化十三子年七 月一日御船手奉行へ達書 既飞江户御中屋敷御普請は寔 そ御大造なる御儀にて跡方に泥候では所詮御新筑は難相 成旧来は銘々片意地飞泥久候故御直飞御下知遊御趣意畏 侯者へ被仰付格別之御省略有用無用之御差図有之甚安 か飞相成諸役人諸職人相励御入用少飞しか子御丈夫飞皆 国中にて御調ひ不日に御満作東都にても御珍敷御手際に て諸向にてる奉感称候趣飞て候云々……

註 2-9. 南紀徳川史第 12 巻 $413 \mathrm{P}$ 文化十二亥年五 月廿二日山中作右衛閥殿より, 御作事奉行見分之場所々 几向後総御材木奉行的立会分之筈奥大奥向二入込候儀 6 御作事奉行之通罷越候事, 御作事役人見分飞罷越候節は 総御材木方役人的罷越候事

註 2-10 南紀徳川史第 2 巻595 P 交政十三年閏三 月廿四日 大納言様前大納言様思召之被為在和歌南竜院 様御霊屋御造営被仰付右御造注御仕入方一被仰付同所 頭取井上兵次郎一手二畏 ミタリ。

註 2-11 南紀徳川史第 2 巻597 P 天保四年二月十 日西浜御殿大奥普請御仕人方被仰付

註 2-12 材木の品質を規制し, 更飞種々の規格が成 立したのは，尾州藩白鳥御材木所の場合る新宮材木問屋 々同様1650年頃である。両者が年代的飞一致する処を見 ると全国的傾向であつた事を推定せしめる一つの根拠 と なろ5。関東支部研第24回発表梗概集所收”拙稿「尾州 藩の木材供給形態に就いて」参照) 